\title{
Bacterial community composition responds to changes in copepod abundance and alters ecosystem function in an Arctic mesocosm study
}

\author{
Tatiana M. Tsagaraki ${ }^{1}$ - Bernadette Pree ${ }^{1} \cdot \varnothing y$ stein Leiknes ${ }^{2} \cdot$ Aud Larsen $^{1,3} \cdot$ Gunnar Bratbak $^{1} \cdot$ Lise $_{\text {Cvreås }}{ }^{1,6}$. \\ Jorun K. Egge ${ }^{1} \cdot{\text { Roman Spanek } \mathbb{D}^{4} \cdot \text { Maria L. Paulsen }}^{1} \cdot$ Yngvar Olsen $^{2} \cdot$ Olav Vadstein $^{5} \cdot$ T. F. Thingstad ${ }^{1}$
}

Received: 6 October 2017 / Revised: 24 May 2018 / Accepted: 11 June 2018 / Published online: 10 July 2018

(c) The Author(s) 2018. This article is published with open access

\begin{abstract}
Combining a minimum food web model with Arctic microbial community dynamics, we have suggested that top-down control by copepods can affect the food web down to bacterial consumption of organic carbon. Pursuing this hypothesis further, we used the minimum model to design and analyse a mesocosm experiment, studying the effect of high $(+Z)$ and low (-Z) copepod density on resource allocation, along an organic-C addition gradient. In the Arctic, both effects are plausible due to changes in advection patterns (affecting copepods) and meltwater inputs (affecting carbon). The model predicts a trophic cascade from copepods via ciliates to flagellates, which was confirmed experimentally. Auto- and heterotrophic flagellates affect bacterial growth rate and abundance via competition for mineral nutrients and predation, respectively. In $+Z$, the model predicts low bacterial abundance and activity, and little response to glucose; as opposed to clear glucose consumption effects in $-\mathrm{Z}$. We observed a more resilient bacterial response to high copepods and demonstrate this was due to changes in bacterial community equitability. Species able to use glucose to improve their competitive and/or defensive properties, became predominant. The observed shift from a SAR11-to a Psychromonodaceae - dominated community suggests the latter was pivotal in this modification of ecosystem function. We argue that this group used glucose to improve its defensive or its competitive abilities (or both). Adding such flexibility in bacterial traits to the model, we show how it creates the observed resilience to top-down manipulations observed in our experiment.
\end{abstract}

Electronic supplementary material The online version of this article (https://doi.org/10.1038/s41396-018-0217-7) contains supplementary material, which is available to authorised users.

Tatiana M. Tsagaraki

tatiana.tsagaraki@uib.no

1 Department of Biological Sciences, University of Bergen, Bergen, Norway

2 Department of Biology, NTNU Norwegian University of Science and Technology, Trondheim, Norway

3 Uni Research Environment, Uni Research AS, Bergen, Norway

4 The Institute of Mechatronics and Computer Engineering, Technical University of Liberec, Liberec, Czech Republic

5 Department of Biotechnology and Food Science, NTNU Norwegian University of Science and Technology, Trondheim, Norway

6 Present address: The University Centre in Svalbard, Longyearbyen, Norway

\section{Introduction}

The microbial food web in the photic zone plays a central role in the oceans' ecosystem functions, such as the cycling of mineral nutrients [1] and oceanic carbon sequestration [2]. It is predicted that Arctic ecosystems will be among the most affected by climate change [3] as freshening, warming and acidification are occurring faster there than in other regions [4-6]. Considering that input of fluvial [7] and glacial $[8,9]$ dissolved organic matter (DOM) and seasonal migration of copepods [10] are central characteristics of the Arctic Ocean, it is highly relevant to understand how (marine) organisms and ecosystem function are coupled in the context of a rapidly changing Arctic [11].

Aristotle's concept of synergy is summarised as "The whole is more than the sum of its parts" and this is particularly true for the oceans role in global carbon cycling. Build-up of carbon through the classical food chain contributes to the production of sinking particles that fuel the Biological Pump (BP) $[12,13]$. Additionally, a large part of 


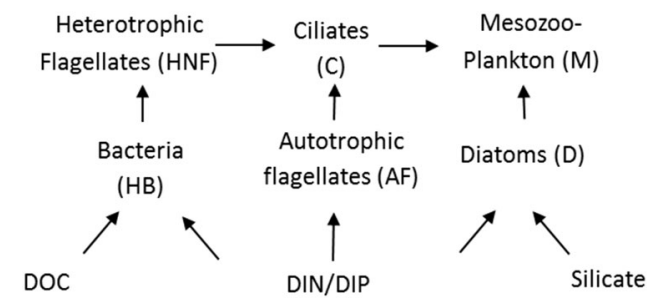

Fig. 1 Minimum food web model redrawn from Thingstad et al. [24]. Dissolved organic carbon (DOC) and mineral nutrients, such as silicate, inorganic nitrogen and phosphate (DIN, DIP) enter the food web via osmotrophic communities, which are preyed upon by phagotrophic communities

dissolved organic carbon (DOC) consumed by microbes is converted into recalcitrant forms via the microbial carbon pump (MCP) [14, 15]. Carbon is sequestered through the BP and the MCP simultaneously and it's rate is hypothesised to vary based on the trophic state of the system [14, 16].

The connection of ecosystem function to diversity, life strategy and trophic interactions is a major challenge in marine microbiology [17] and in order to gain a predictive understanding of community dynamics and function, the integration of theory with models and experimental data is required [18]. Several studies look at these aspects for selected groups, e.g. bacterial diversity and carbon cycling [19], predator life strategy and carbon sequestration [20], competition within phytoplankton groups at different $\mathrm{CO}_{2}$ conditions [21]. Few studies address these questions at the food web level (e.g. [22, 23]). Both these studies suggest that the community dynamics and structure play a pivotal role in the form and quantity of food web mediated export.

In an attempt to understand how trophic interactions affect the structure and function of the microbial food web we have used a 'minimum' mathematical food web model [24] to interpret the results of mesocosm experiments. The minimum model has so far reproduced observed system responses of two bottom-up manipulation experiments in Ny Ålesund, Svalbard. However, model and experimental results have suggested that copepod abundance is a major influence in the structure and function of Arctic food webs [25]. Further, the initial copepod standing stock has also been suggested to affect bacterial and virus communities, where high copepods were connected to mineral nutrient limited heterotrophic prokaryotes while low copepods associated with carbon limited heterotrophic prokaryotes [26]. The latter study provides an example of how rapid dynamics of the trophic interactions within the microbial food web created strong coupling through ca. 5 orders of magnitude in organism size (copepods -viruses), affecting nutrients and carbon cycling. Even though our minimum model has pointed to the regulating effect of top predators,
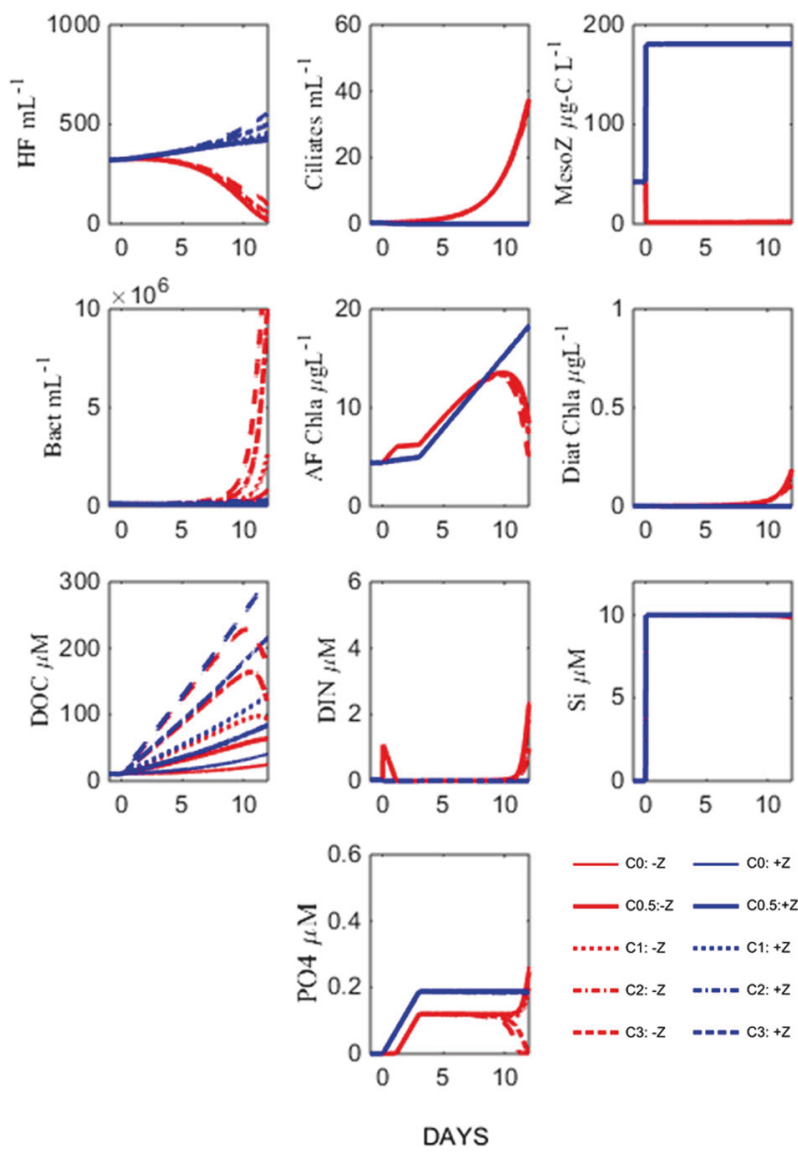

Fig. 2 Hypothesised responses of abundances and biomasses of microbial communities represented in the minimum food web model [24] to copepod and carbon manipulations. The blue and red lines represent Z+ and Z- treatments, respectively. The glucose gradients are indicated by line thickness increasing with increasing glucose additions

the predator community has not been manipulated experimentally before.

To test our hypothesis of strong top predator control on organic carbon and mineral nutrient cycling in the marine microbial food web, we designed a new mesocosm experiment in an Arctic location (Ny Ålesund, Svalbard) where we contrasted high and low copepod abundance along a gradient of carbon additions. The "minimum" food web model (Fig. 1), was used to model responses for each mesocosm (Fig. 2). This model output represents our hypotheses for the outcome of the experiment and can be summarised as:

High copepod abundance $(+Z)$ triggers a trophic cascade where low ciliate abundance, releases the grazing pressure on auto- and heterotrophic flagellates. The two flagellate populations constrain bacterial abundance through increased mineral nutrient competition and predation, respectively, resulting in reduced glucose 
consumption which means no differences in bacterial abundance are expected along the carbon gradient.

Removal of mesozooplankton grazers ( $-Z$ ), leads to high ciliate abundance, creating conditions with low mineral nutrient competition and low grazing pressure for bacteria. The expected results are high bacterial abundance and glucose consumption, and consequently that bacterial abundance will scale to the amount of glucose addition. Combined with silicate addition, removal of the copepod grazers creates a niche for diatoms, which in Fig. 2 appear in the $-Z$ treatments.

\section{Materials and Methods}

\section{Mesocosm setup and manipulations}

The mesocosm experiment was conducted in Kings Bay on the east coast of Svalbard from 26th June 8th July 2015. We used ten $1250 \mathrm{~L}$ high-density translucent polyethylene tanks (Ecobulk MX; Schütz, Selters, Germany) as experimental units. The filling procedure and copepod manipulations are described in detail in the SI.

At start of the experiment (after time zero sampling) we added 5 adult copepods per litre to one set of five tanks $(+Z$ tanks) while the remaining five tanks were kept at low initial copepod abundance ( $\mathrm{Z}$ tanks). Nutrients, i.e. ammonia, phosphate and glucose in aqueous stocks was added daily from day one, resulting in two carbon to mineral nutrient ratio gradients (one for $+\mathrm{Z}$ and one for $-\mathrm{Z}$ ) with $C=0,0.5,1,2$, and $3 \times$ Redfield $(1 \times$ Redfield $=$ $7.4 \mu \mathrm{MC}, 1.12 \mu \mathrm{MN}$ and $0.07 \mu \mathrm{MP})$. Si was added in surplus $(11.4 \mu \mathrm{M})$ on day 1 and after that $1.2 \mu \mathrm{M} \mathrm{Si}$ was added every second day to maintain it in surplus. The tanks were accordingly denoted $-\mathrm{Z}$ : $0 \mathrm{C}-3 \mathrm{C}$ and $+\mathrm{Z}$ : $0 \mathrm{C}-3 \mathrm{C}$.

\section{Analysis of dissolved constituents}

Dissolved inorganic phosphate, silicate, and ammonium were measured immediately after sampling according to the methods described in Koroleff [27], Valderrama [28], and Holmes et al. [29], respectively.

Samples for total organic carbon (TOC) were collected in $30 \mathrm{ml}$ acid washed high-density polyethylene bottles and stored frozen $\left(-20^{\circ} \mathrm{C}\right)$ until analysis. TOC concentrations were determined by high temperature combustion $\left(720^{\circ} \mathrm{C}\right)$ using a Shimadzu TOC-V CPH-TN carbon and nitrogen analyser (Shimadzu Corporation) according to Cauwet [30]. The instrument was calibrated using a standard series of acetoanilide and quality controlled using carbon reference material provided by the Hasell consensus reference material programme (Hansell Lab, U. Miami, USA).
Particulate organic carbon (POC) samples were filtered in triplicates onto pre-combusted $\left(450{ }^{\circ} \mathrm{C}\right.$, overnight), 25 $\mathrm{mm}, \mathrm{GF} / \mathrm{F}$ filters (Whatman). Filtration volumes varied between 100 and $400 \mathrm{ml}$, filters were kept frozen $\left(-20^{\circ} \mathrm{C}\right)$ until analysis. The filters were fumed with saturated $\mathrm{HCl}$ and analysed according to Pella and Colombo [31] in a Flash 2000 elemental analyser (Thermo Fisher Scientific, Waltham, MA, USA).

DOC was calculated as TOC minus POC from day 3 onwards.

\section{Quantification of abundances and biomasses}

On day zero, subsamples for mesozooplankton were collected. Samples from the $-\mathrm{Z}$ tanks (day zero and 13), and from the $+Z$ tanks (day 13) were collected by pumping $80-100 \mathrm{~L}$ of water from the tanks while they were mixed. This water was then filtered using a $20 \mu \mathrm{m}$ plankton sieve. Representatives of the genus Calanus were identified to species based on morphology and prosome lengths of individual copepodite stages based on the size distribution by Kwasniewski et al. [32]. Biomass was calculated using length-dry weight conversions from Hay et al. [33] and Hay et al. [34] assuming a carbon content of $45 \%$ [35].

Ciliate abundance was quantified using a black and white imaging FlowCAM ${ }^{\circledR}$ II (Fluid Imaging Technologies, Maine, USA). Fresh samples were run for 30 min using a $10 \times$ objective, in Auto Image mode. Ciliates and dinoflagellates were sorted manually by visual inspection of the image database.

Heterotrophic nanoflagellates (HNF) and bacteria was determined using an Attune ${ }^{\circledR}$ Acoustic Focusing Flow Cytometer (Applied Biosystems by Life technologies) with a syringe-based fluidic system and a $20 \mathrm{~mW} 488 \mathrm{~nm}$ (blue) laser. Samples were fixed with glutaraldehyde $(0.5 \%$ final conc.), flash frozen in liquid nitrogen and stored at $-80^{\circ} \mathrm{C}$. Prior to analyses samples were thawed and stained with SYBR Green I (Molecular Probes, Eugene, Oregon, USA) for a minimum of $1 \mathrm{~h}$. Heterotrophic bacteria were analysed using a flow rate of $25 \mu \mathrm{l} \mathrm{min}{ }^{-1}$ and $\mathrm{HNF}$ at $500 \mu \mathrm{min}^{-1}$, following protocols modified from Marie et al. [36] and Zubkov et al. [37]. For bacteria, flow cytometer plots showed two distinct populations, corresponding to different (high and low) nucleic-acid staining properties. Briefly, these populations are discriminated based the red and green fluorescence after staining with SYBR green. The stain reflects the amount of DNA in each cell and these, referred to as HNA and LNA bacteria, are attributed different properties connected to activity and size [38-45]. From day 7-8 of the experiment, a subpopulation of HNA, with higher red and green fluorescence signal, appear in carbon-amended tanks (Fig. S2). Relative abundance of this subgroup 
abundance was calculated in all tanks throughout the experiment.

Chlorophyll $a$ was filtered onto $47 \mathrm{~mm}$ Nuclepore filters and analysed fluorometrically according to Holm-Hansen and Riemann [46]. Total chl $a(>0.2 \mu \mathrm{m})$ was filtered in triplicates every second day and fractionated chl $a$ on filters of pore sizes $0.2,0.8$ and $10 \mu \mathrm{m}$ on the days between total chl $a$. Chl $a$ was extracted in methanol at $4{ }^{\circ} \mathrm{C}$ overnight before measuring on a Turner Designs 10-AU Fluorometer calibrated with pure chl $a$ (Sigma Chemicals Inc.).

\section{Determination of biological rates}

The production of biomass by heterotrophic bacteria was quantified by incorporation of ${ }^{3} \mathrm{H}$ leucine into macromolecules (protein biosynthesis). Radioactive leucine was added to the samples at a final concentration of $40 \mathrm{nM}$, incubated for $1 \mathrm{~h}$ at ambient temperature $\left( \pm 1^{\circ} \mathrm{C}\right)$, stopped by addition of trichloracetic acid, and processed by the centrifugation method [47]. Incorporation of ${ }^{3} \mathrm{H}$ was quantified by liquid scintillation counting (PerkinElmer Life and Analytical Sciences, Waltham, MA, USA), and the production of biomass by heterotrophic bacteria was quantified on a carbon basis in accordance with Kirchman [48] assuming no isotope dilution.

\section{Molecular analysis of bacterial community composition}

Samples for molecular analyses focused on 6 of the 10 treatments, 3 tanks with low copepod abundance $(-\mathrm{Z}$ : 0C, 1C, 3C) and 3 tanks with high copepod abundance ( $+\mathrm{Z}: 0 \mathrm{C}$, 1C, 3C). Samples were collected every second day onto $0.2 \mu \mathrm{m}$ Sterivex filters $(1-31)$. The V4 region of the $16 \mathrm{~S}$ rRNA gene was used for the sequence based amplification generation, with indexing and sequencing of amplicon libraries using the MiSeq Platform at the Norwegian Sequencing Centre (Oslo, Norway). See SI for more details on sample storage, extraction, amplification and sequencing.

\section{Bioinformatic analysis}

The 16S rRNA sequences were processed using Mothur [49], including quality filtering and chimera check using the Pyro Noise implemented in Mothur [50] and chimera UCHIME [51]. The sequences were aligned against the SILVA database (version 123). Mitochondrial and chloroplast sequences were removed prior to OTU construction. Alignments were constructed using Needleman-Wunsch pairwise alignment method implemented as align.seqs command in Mothur [52]. All OTUs were constructed using a $97 \%$ sequence identity cut-off. Singletons were removed before clustering and all singletons were subsequently linked to taxonomy file in order to know what kind of sequences that were cut from the datasets. Size (number of sequences) of all samples was normalised to the size of the smallest sample [53]."

\section{Statistical analysis}

Trophic cascades are defined as a negative correlation between the biomasses or abundances of adjacent trophic levels and a positive one between trophic levels two links apart ([54, 55], reviewed by [56]). We run a Pearson correlation (IBM SPSS) between abundance of ciliates, total chl $a$ biomass (as a proxy for autotrophic flagellates), and HNF and bacteria abundance on days $3,5,7,9,11$. The trophic links assumed follow Fig. 1, excluding diatoms. We pooled all treatments and days together because the trophic cascade should work across both + and $-Z$ in the same way.

\section{Model description}

The mathematical formulation of the 'minimum' microbial food web model (Fig. 1) is described in detail in Thingstad et al. [24]. Briefly, the model consists of six plankton functional types (PFT) and uses phosphorus (P) as the basic unit. Specific growth rates are defined as hyperbolic curves defined by their maximum value $\left(\mu^{\max }\right)$ and slope at 0 resource concentration $(\alpha)$, i.e. representing maximum clearance rate for phagotrophs and maximum phosphate affinity for osmotrophs. A yield parameter is associated with each phagotroph, defining how much of the $\mathrm{P}$ of prey biomass, ends up in predator biomass, the surplus is assumed to be instantaneously remineralised to free orthophosphate. Bacterial and diatom growth can either be limited by $\mathrm{P}$, or by biodegradable DOC and by free silicate, respectively. The original set of parameters [24], established for a system with higher tempereture (ca $10^{\circ} \mathrm{C}$ ), was used but all $\mu^{\max }$ and $\alpha$ values are divided by 1.4 to include the temperature correction suggested by Larsen et al. [25].

The initial state was calculated by assuming the microbial part to be in steady state. This steady state is a function of the amount of mesozooplankton $\left(\mathrm{Z}_{0}\right)$, the total-P available to the microbial part $\left(\mathrm{P}_{\mathrm{T} 0}\right)$, and the model parameters. Calculation of the initial steady state is simplified by assuming all food uptakes to be proportional to food concentration. This approximation to steady state becomes better the more food limited the organisms are.

At time $=0$, the mesozooplankton stocks in $+\mathrm{Z}$ were changed and nutrient additions initiated, mimicking the different mesocosm treatments. The simulated $\mathrm{P}$ concentrations were converted to units comparable with 
Table 1 Pearson correlation coefficient and significance levels between ciliates, HNF, Chla and bacteria for all tanks and experimental days

Pearson correlation

\begin{tabular}{lllll}
\hline & Ciliates & HNF & Bacteria & Chla \\
\hline Ciliates & & & & \\
Pearson correlation & 1 & $-0.620^{* *}$ & $0.582^{* *}$ & $-0.477^{* *}$ \\
Sig. (2-tailed) & & 0 & 0 & 0 \\
$N$ & 50 & 50 & 50 & 50 \\
$H N F$ & & & & \\
Pearson correlation & $-0.620^{* *}$ & 1 & -0.048 & $0.796^{* *}$ \\
Sig. (2-tailed) & 0 & & 0.741 & 0 \\
$N$ & 50 & 50 & 50 & 50 \\
Bacteria & & & & \\
Pearson correlation & $0.582^{* *}$ & -0.048 & 1 & -0.001 \\
Sig. (2-tailed) & 0 & 0.741 & & 0.993 \\
$N$ & 50 & 50 & 50 & 50 \\
Chla & & & & \\
Pearson correlation & $-0.477^{* *}$ & $0.796^{* *}$ & -0.001 & 1 \\
Sig. (2-tailed) & 0 & 0 & 0.993 & \\
$N$ & 50 & 50 & 50 & 50 \\
\hline
\end{tabular}

**Correlation is significant at the 0.01 level (2-tailed).

observations using fixed conversion factors. Further details of the model, parameters and conversion factors are given in SI.

\section{Results}

\section{Abundances, biomasses}

Correlation analysis of abundances of ciliates, HNF, bacteria and total chl $a$ concentrations revealed presence of a trophic cascade from copepods to bacteria with significant negative correlations between ciliates and their prey (HNF and total $\operatorname{chl} a$ ) and a negative one, although not significant, between HNF and their prey (bacteria) (Table 1). There was also a statistically significant positive correlation between ciliates and bacteria.

Abundances of microbial communities, mesozooplankton biomass, concentrations of chl $a$, DOC and mineral nutrients over the course of the experiment are shown in Fig. 4. Where mesozooplankton $>200 \mu \mathrm{m}$ were removed ( $-\mathrm{Z}$ ), their biomass decreased from $22 \mu \mathrm{g} \mathrm{C}{ }^{-1}$ at the start of the experiment to $5 \pm 2 \mu \mathrm{g} \mathrm{C}{ }^{-1}$ (mean $\pm \mathrm{SD}$ ) at the end. Ciliates increased rapidly from day 3 onwards, from initial abundances of less than 1 ciliate per ml to $118 \pm$ 24 ciliates per $\mathrm{ml}$ on day 11 . Heterotrophic nanoflagellate initial abundance was $620 \pm 65$ cells per $\mathrm{ml}$ and increased to
$1280 \pm 144$ cells per $\mathrm{ml}$ on day 1 . The abundance of HNF decreased to less than 50 cells per $\mathrm{ml}$ in $0 \mathrm{C}$ tanks towards the end of the experiment. In tanks with $\mathrm{C}$ additions, HNF increased to around 500 cells per $\mathrm{ml}$ towards the end. Bacteria abundance was $0.8 \pm 0.0 \times 10^{6}$ cells per $\mathrm{ml}$ and remained stable until day 8 . After that, bacteria increased to peak abundances of $4.9 \pm 0.9 \times 10^{6}$ cells per ml, with a maximum in tanks with $1 \mathrm{C}$ addition $\left(5.8 \times 10^{6}\right.$ cells per ml $)$ and minimum in the $0 \mathrm{C}$ tank $\left(3.4 \times 10^{6}\right.$ cells per $\left.\mathrm{ml}\right)$. Autotrophs were dominated by the fraction of cells $<10 \mu \mathrm{m}$ throughout the experiment and were not affected by carbon additions. Total chl $a$ concentration remained at levels similar to initial values $\left(1.6 \pm 0.0 \mu \mathrm{g}\right.$ chl $\left.a 1^{-1}\right)$ for 5 days and after a peak of $3.0 \pm 0.3 \mu \mathrm{g} \mathrm{chl} a 1^{-1}$ it decreased to initial concentrations.

In $+\mathrm{Z}$ tanks, the final biomass of mesozooplankton (300 $\pm 110 \mu \mathrm{g} \mathrm{C} 1^{-1}$ ) was more than tenfold higher than initial biomass $\left(22 \mu \mathrm{g} \mathrm{C} \mathrm{l}^{-1}\right)$. The added copepods consisted of Calanus finmarchicus and $C$. glacialis copepodites, stage 4 and 5. Analysis of the $-\mathrm{Z}$ tanks at the end of the experiment showed some small copepods, consisting mainly of copepodite nauplii and Oithona sp. Ciliates remained at abundances less than 1 cell per $\mathrm{ml}$ throughout the experiment which allowed for HNF to increase from $620 \pm 78$ cells per $\mathrm{ml}$ to approximately 3000 cells per $\mathrm{ml}$ on days $8-9$. The abundance of HNF was slightly lower in $0 \mathrm{C}$ tanks, with a maximum of 2690 cells per $\mathrm{ml}$ at the end of the experiment. Bacteria decreased to half of their initial abundances of 0.8 $\pm 0.0 \times 10^{6}$ cells per ml until day 7 . Thereafter it increased to a maximum of $2.5 \pm 0.4 \times 10^{6}$ cells per $\mathrm{ml}$, with the lowest abundance in $0 \mathrm{C}$ tanks $\left(2.2 \times 10^{6}\right.$ cells per $\left.\mathrm{ml}\right)$. The autotrophic community was dominated by cells $<10 \mu \mathrm{m}$ and increased throughout the experiment. The bloom had highest maximum concentrations of $11.7 \mu \mathrm{g}$ chl $a 1^{-1}$ in $0 \mathrm{C}$ tanks. Total chl $a$ levelled off at $7.6 \pm 0.5 \mu \mathrm{g} \mathrm{chl} a 1^{-1}$ in the other tanks at the end of the experiment. Chysophyseas (Meringosphaera sp) and small naked dinoflagellates, in addition unidentified flagellates dominated the phytoplankton community $>10 \mu \mathrm{m}$ (J. Egge, personal communication).

\section{Mineral nutrients, DOC}

Silicate concentrations increased in all tanks from $0.9 \pm$ $0.0 \mu \mathrm{M}$ to $18.2 \pm 0.6 \mu \mathrm{M}$ in the end of the experiment (Fig. 3). In $+\mathrm{Z}$ tanks ammonium $\left(\mathrm{NH}_{4}{ }^{+}\right)$concentrations remained at levels $<0.8 \mu \mathrm{M}$ but increased in $-\mathrm{Z}$ tanks until the end of the experiment with peaks of $4.6 \mu \mathrm{M}, 2.2 \mu \mathrm{M}$, $1.1 \mu \mathrm{M}, 0.6 \mu \mathrm{M}$ and $0.6 \mu \mathrm{M}$ in the $0 \mathrm{C}, 0.5 \mathrm{C}, 1 \mathrm{C}, 2 \mathrm{C}, 3 \mathrm{C}$ tanks, respectively. Concentration of $\mathrm{PO}_{4}{ }^{3-}$ increased tenfold in all tanks from $0.03 \mu \mathrm{M}$ until day 5 and then decreased in all tanks with $\mathrm{C}$ additions to $0.10 \mu \mathrm{M}$. Tanks with $0 \mathrm{C}$ and $0.5 \mathrm{C}$ additions were exceptions, there $\mathrm{PO}_{4}{ }^{3}$ 
Fig. 3 Measured standing stocks and dissolved nutrients arranged as in Fig. 2. Red and blue curves correspond to $-\mathrm{Z}$ and $+\mathrm{Z}$ treatments, respectively. The glucose gradients $(0,0.5,1,2$ and $3 \times$ Redfield) are represented by the symbol sequence $(O, \Delta$, $\square, \nabla, 0)$
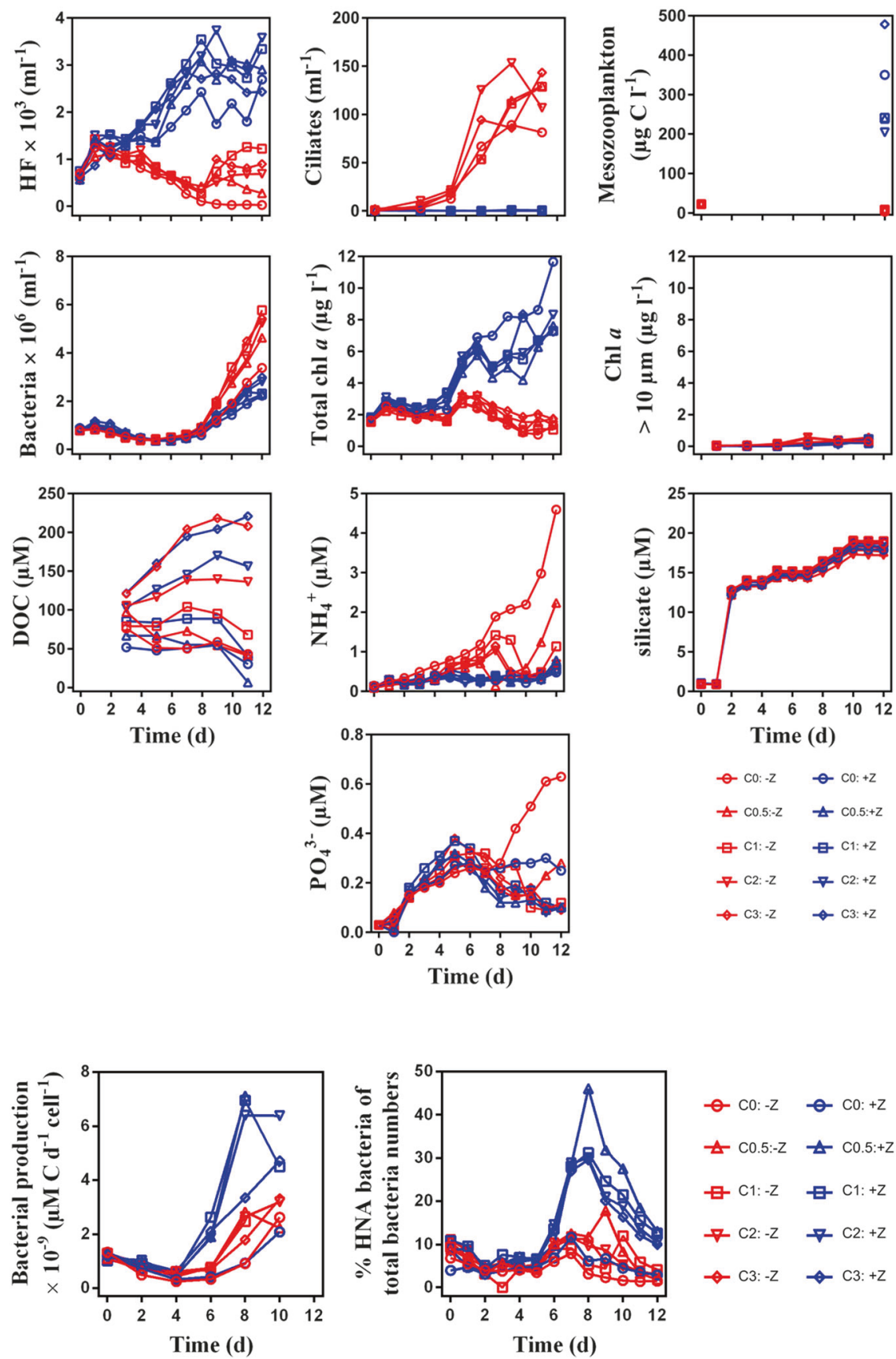

Fig. 4 a Bacterial production per cell. b Relative abundance of the subgroup of HNA bacteria (="Winnie-the Pooh" strategists) of total bacterial abundances. The glucose gradients $(0,0.5,1,2$ and $3 \times$ Redfield) are represented by the symbol sequence $(O, \Delta, \square$, $\nabla, \diamond)$

- peaked at $0.63 \mu \mathrm{M}$ in $-\mathrm{Z}$ : $0 \mathrm{C}, 0.28 \mu \mathrm{M}$ in $-\mathrm{Z}: 0.5 \mathrm{C}$ and $0.25 \mu \mathrm{M}$ in $+\mathrm{Z}: 0 \mathrm{C}$ tanks. DOC concentrations were similar in tanks with the same $\mathrm{C}$ additions and increased from day 3 onwards in $2 \mathrm{C}$ and $3 \mathrm{C}$ tanks from $121 \mu \mathrm{M}$ to $214 \mu \mathrm{M}$ and $104 \mu \mathrm{M}$ to $146 \mu \mathrm{M}$, respectively. In the tanks with $1 \mathrm{C}, 0.5 \mathrm{C}$ and $0 \mathrm{C}$ additions, concentrations decreased to $82 \mu \mathrm{M}, 59$ $\mu \mathrm{M}$ and $30 \mu \mathrm{M}$, respectively.

\section{Bacterial activity and diversity}

Initial bacterial production was $1.2 \pm 0.1 \times 10^{-9} \mu \mathrm{MC} \mathrm{d}^{-1}$ cell $^{-1}$ and decreased in all tanks until day 4 to rates less than half the initial value (Fig. 4a). In $-\mathrm{Z}$ tanks bacterial production per cell increased from day 6 onwards to a maximum of $2.8 \pm 0.5 \times 10^{-9} \mu \mathrm{M} \mathrm{C} \mathrm{d}^{-1}$ cell $^{-1}$, with lowest rates in tanks with 0 and $0.5 \mathrm{C}$ additions. In $+\mathrm{Z}$ tanks with $\mathrm{C}$ additions bacterial production per cell increased to a peak of $6.3 \pm 1.1 \times 10^{-9} \mu \mathrm{MC} \mathrm{d}^{-1}$ cell $^{-1}$ on day 8 and 10 , and $2.1 \times 10^{-9} \mu \mathrm{MC} \mathrm{d}^{-1}$ cell $^{-1}$ in the tank with no $\mathrm{C}$ added. The peak in bacterial production per cell in $+\mathrm{Z}$ tanks coincides with a peak of a subgroup of HNA bacteria, detected by flow cytometry (Fig. S1). Until day 6, this group, generally considered larger and more active than LNA bacteria [41-45] made up approximately $10 \%$ of 


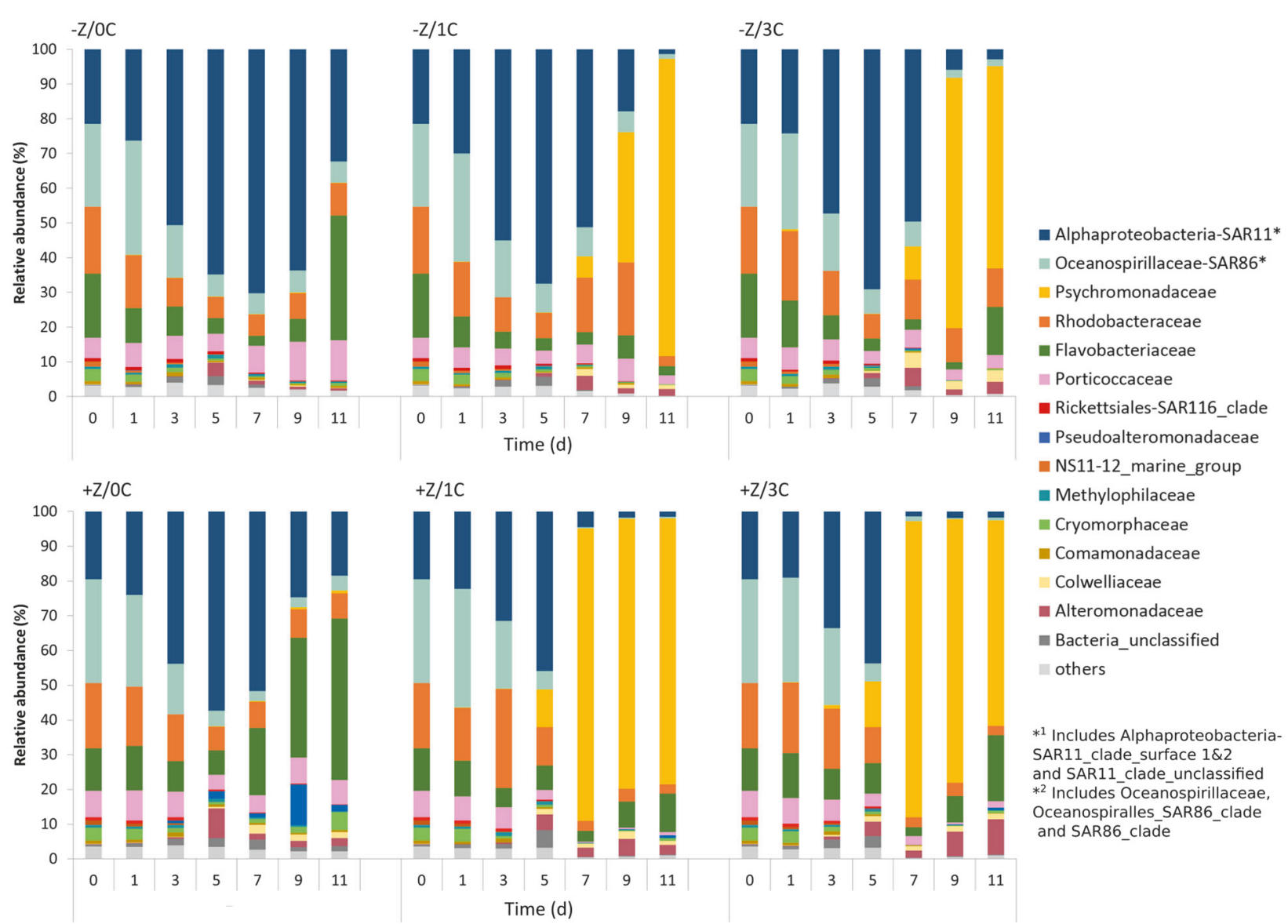

Fig. 5 Prokaryote community composition demonstrating how the Alphaproteobacteria-SAR11-dominated community was replaced by a Psychromonadaceae dominated one in glucose-amended tanks

the total bacterial abundance (Fig. 4b). In $+\mathrm{Z}$ tanks withadded $\mathrm{C}$, the subgroup of HNA bacteria increased after day 6 on and peaked on day 8 , when they made up $34 \pm 8 \%$ of the total bacterial abundance, in $+1 \mathrm{C}$ they even reached $46 \%$, while remaining at levels $<10 \%$ throughout the experiment in the $+\mathrm{Z}$ tank with no $\mathrm{C}$ additions. Abundances of the subgroup of HNA bacteria in $-\mathrm{Z}$ tanks did not exhibit pronounced changes in any of the tanks at any time in the experiment, but was lowest for the 0C tank. For comparison, the total bacterial production is presented in Figure S3: Initial average total bacterial production was $0.98 \mu \mathrm{MC} \mathrm{L}^{-1} \mathrm{~d}^{-1}$. From day 8 onwards total bacterial production increases, less so in the tanks with no $\mathrm{C}$ addition, with no marked differences between $+\mathrm{Z}$ and $-\mathrm{Z}$ or along the carbon addition gradient.

A total number of 3,711,093 sequence reads were received from the sequencing centre in Oslo. After quality trimming and chimera removal, the complete $16 \mathrm{~S}$ rRNA gene dataset comprised 3,436,777 reads from 6 tanks, with an average number of 572,796 reads/ tank. The bacterial community was dominated by typical marine taxa including the Alpha- and Gammaproteobacteria and Flavobacteria. The relative abundance of these taxa varied over time and with the treatments. A succession was seen with organisms affiliated to Oceanospirillaceae-SAR86 (which includes Oceanospirillaceae, Oceanospiralles_SAR86_clade and SAR_86_clade) being most predominant at the beginning of the experiment, followed by Alphaproteobacteria-SAR11 (which includes Alphaproteobacteria-SAR11_clade_surface 1\&2 and SAR11_clade_unclassified) (Fig. 5). On day 5, Alphaproteobacteria-SAR11 were dominating in all mesocosms, but declined from then on. We then observed a different trend in the tanks with added glucose, where a distinct community shift was seen towards the predominance of Psychromonadaceae. In the $+\mathrm{Z}$ tanks Psychromonodaceae increased from 11 and $13 \%$, on day 0 for $+\mathrm{Z}: 1 \mathrm{C}$ and $+\mathrm{Z}: 3 \mathrm{C}$ respectively, to $>80 \%$ of the sequence reads. In $-\mathrm{Z}$ tanks, the shift towards Psychromonadaceae- dominance occurred later. Tanks without glucose addition, shifted towards a predominant Flavobacteriaceae $(>30 \%)$ population. 

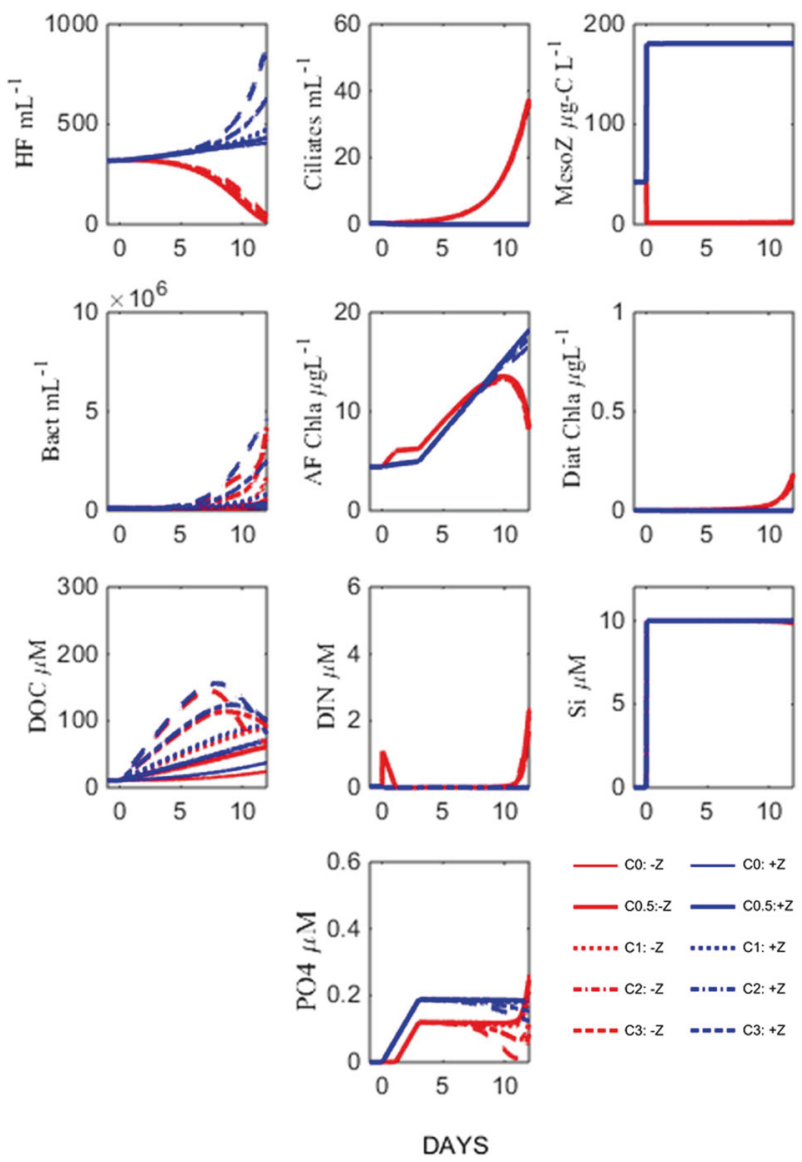

Fig. 6 Model run with two groups of bacteria, one group with the same parameters as in the initial model and one Winnie-the-Pooh strategist group with reduced clearance rate (from heterotrophic flagellates) and increased mineral nutrient affinity when free glucose is present (see SI for details). Thereby, the difference in modelled bacterial abundance and DOC levels between the $+\mathrm{Z}$ and $-\mathrm{Z}$ levels is reduced compared to the initial model run (Fig. 2). The blue and red lines represent $Z+$ and $\mathrm{Z}$ - treatments, respectively

\section{Discussion}

Our experimental results were in good agreement with the dynamics of our minimum model (Fig. 2). However, in the treatments with high copepod levels and added carbon, observed bacterial density, production per cell, and ability to consume glucose were much higher than predicted by the model. We argue that this discrepancy can be traced back to internal changes in the bacterial community, not represented in the minimum model.

Initially Alphaproteobacteria-SAR 11, a group capable of utilising glucose at low concentrations [57], and Oceanospirillaceae, whose members are able to degrade complex organic compounds [58], dominated the bacteria community. In the tanks amended with glucose and copepods, Psychromonadaceae, which have a known preference to glucose as a C source [59], replaced these taxa. This switch in community composition, not observed in the 0C-tank, was a clear response to the organic carbon addition. Flavobacteria have an ability to break down complex organic matter by direct attachment and exo-enzymatic attack of algal cells and algal-derived detrital particles [60-62] and are therefore characterised as important 'first responders' to phytoplankton blooms. They were recently connected to phytoplankton blooms in Arctic waters [63]. The observed increased contribution of Flavobacteria to total community diversity when no organic carbon was supplied, can thus be seen as a typical response to environmental conditions where the bacteria are dependent on an autochthonous organic carbon source, in this case provided by the blooming phytoplankton.

The shift in bacterial community composition in the presence of glucose occurred for both zooplankton treatments. In the presence of copepods, however, the Psychromonadaceae-dominance occurred earlier than when copepods were absent, suggesting a stronger selection for these under high flagellate grazing. In contrast to model predictions, we observed higher prokaryote production per cell in $+\mathrm{Z}:+\mathrm{C}$ than in $-\mathrm{Z}:+\mathrm{C}$, even though no pattern was detected in the total BP. The higher production combined with the lower bacterial abundance in the $+\mathrm{Z}$ : $+\mathrm{C}$ treatments imply that per-cell activity was also higher. This seems to indicate higher protein synthesis per cell in $+Z$ treatments, but may in principle also mean a reduced isotope dilution. The leucine-based bacterial production estimates are calculated with the same dilution factor $(=1)$ in both cases. As we have used also a fixed conversion factor of leucine to carbon, bacterial C-production in mesocosms with particularly C-rich bacteria would be underestimated. Higher copepod density thus seemed to have a bottom-up effect on the prokaryotes, although opposite to that predicted by the minimum model.

Contrary to the original model, we also found little effect of the + : $-\mathrm{Z}$ manipulations on measured DOC levels (Fig. 3). Combining the higher leucine-based estimates for bacterial production in $+Z$ treatments with an assumption of constant yield would lead to an expectation of higher consumption and therefore lower DOC concentrations in the $+\mathrm{Z}$ treatments. As these calculations are influenced by both the leucine - carbon conversion factor, bacterial respiration, and allochthonous DOC production, it is difficult to separate the underlying mechanisms.

We also observed an increase of a subgroup of HNA bacteria, shown to be larger in size [38] and more active [64] than LNA bacteria [42]. The abundance of the HNA bacteria subgroup increased slightly with glucose addition, but the main effect was due to copepod manipulations, with high abundances of the subgroup of HNA bacteria in $+\mathrm{Z}$ treatments (Fig. S2). Assuming larger bacteria to be less edible by heterotrophic flagellates, this predation effect fits 
reports where experimentally increased predation pressure selects for inedible bacteria [65-67]. The same effect has been shown to be enhanced under phosphate-limited (glucose-replete) conditions [68]. Cells that use excess glucose to increase size will, theoretically, have a potential to increase their competitiveness for mineral nutrients by increasing their surface without simultaneously increasing their cell quota of limiting mineral nutrients. Based on these observations, we suggest that the successful Psychromonadaceae belong to what has been proposed as "Winnie-thePooh" strategists [69]: organisms that use a non-limiting substrate to simultaneously increase competitiveness and defence.

To illustrate the effect of such a bacterial strategy on ecosystem functioning, we added an extra group of bacteria to the minimum model (Fig. 6, Fig. S1). This group mimics the Winnie-the-Pooh strategy by simultaneously reducing clearance rate (from heterotrophic flagellates) and increasing mineral nutrient affinity when free glucose is present (see SI and Fig S1 for details). With this modification, the difference in modelled bacterial abundance and DOC levels between the $+\mathrm{Z}$ and $-\mathrm{Z}$ levels is reduced (Fig. 6); bringing model results closer to the corresponding experimental results. Interestingly, the need for more than one bacterial PFT was speculated when originally developing the minimum model for a mesocosm experiment with glucose addition in a Danish fjord [24], where the authors argued that the one-PFT bacterial representation could not simultaneously reproduce both the level and the pattern observed in bacterial production.

The Atlantic Arctic and Atlantic subarctic areas (sensu [70]) display among the highest mean daily POC fluxes in the world oceans [71]. The fluxes are strongly connected to the planktonic community composition in these areas [72] with commonly occurring diatom and Phaeocystis blooms, accounting for the highest carbon export potentials. With the $\geq 1$ year needed for the reproductive cycle of Arctic copepods [73], the trophic cascade observed in our experiment could well reflect the response of the upper ocean when copepods rise in the water column after the winter diapause. As a response to increased predation pressure in $+\mathrm{Z}$ the bacterial community diversified faster and invested resources into defence against predators, through increase in cell size. With high abundance of copepods, HNF and primary producers (Fig. 3), more carbon ends up in the POC pool, therefore suggesting higher export potential through the BP.

In $-Z$, ciliates rapidly become the top predators and via the absence of nanoflagellates and large autotrophic flagellates the microbial loop remains active in converting carbon into more refractory forms. However the same lack of larger autotrophs and predators suggests that particulate carbon export will be reduced in this setup, rendering bacterial consumption of organic carbon a more major pathway for carbon cycling

Where ciliates are the key predators $(-\mathrm{Z})$, nutrient cycling processes continue within the microbial loop but the absence of flagellates and large autotrophs means the connection to higher trophic levels is severed. Accumulation of particulate organic material will then be lower and bacterial degradation of carbon would become a more important pathway for carbon cycling in this system. As bacterial degradation of carbon has been found to produce mostly recalcitrant forms [74] we hypothesise that even though the DOC supply is high, more carbon would be sequestered into dissolved forms than moving up the food chain, where it would end up contributing more to the BP. Thus with copepods absent or arriving later in the season, we could observe the counterintuitive scenario that more organic carbon supply in the photic zone gives less particulate organic carbon accumulation within the microbial food web [75].

Published work from the Arctic, indicates substantial and often rapid changes in top predator community (e.g. [76-78]) with subsequent effects on community production. Our results suggest that changing patterns of top-down predation and carbon supply in the Arctic can have important consequences on how carbon is allocated in the food web and how modifications in life strategy influence consumption and allocation patterns.

Acknowledgements Financial support was provided by the Norwegian Research Council funded project Micropolar (225956/E10) and the European Commission funded project Ocean Certain (FP7-ENV2013-6.1-1; no: 603773). We would like to thank Elzbieta A. PetelenzKurdziel and Evy Foss Skjoldal for technical assistance and Colin A. Stedmon for assistance with TOC analysis. We would like to thank all participants of the mesocosm experiment for their contribution in setting up and running the experiment. Finally we would also like to thank Kings Bay AS and the Norwegian Polar Institute for hosting and logistical support in Ny Ålesund.

\section{Compliance with ethical standards}

Conflict of interest The authors declare that they have no conflict of interest.

Open Access This article is licensed under a Creative Commons Attribution 4.0 International License, which permits use, sharing, adaptation, distribution and reproduction in any medium or format, as long as you give appropriate credit to the original author(s) and the source, provide a link to the Creative Commons license, and indicate if changes were made. The images or other third party material in this article are included in the article's Creative Commons license, unless indicated otherwise in a credit line to the material. If material is not included in the article's Creative Commons license and your intended use is not permitted by statutory regulation or exceeds the permitted use, you will need to obtain permission directly from the copyright holder. To view a copy of this license, visit http://creativecommons. org/licenses/by/4.0/. 


\section{References}

1. Arrigo KR. Marine microorganisms and global nutrient cycles. Nature. 2005;437:349-55.

2. Jiao N, Robinson C, Azam F, Thomas H, Baltar F, Dang H, et al. Mechanisms of microbial carbon sequestration in the ocean future research directions. Biogeosciences. 2014;11:5285-306.

3. Riebesell U, Gattuso JP, Thingstad TF, Middelburg JJ. Preface "Arctic ocean acidification: pelagic ecosystem and biogeochemical responses during a mesocosm study". Biogeosciences. 2013;10:5619-26.

4. Engel A, Borchard C, Piontek J, Schulz KG, Riebesell U, Bellerby R. $\mathrm{CO}_{2}$ increases ${ }^{14} \mathrm{C}$ primary production in an Arctic plankton community. Biogeosciences. 2013;10:1291-308.

5. AMAP. AMAP Assessment 2013: Arctic Ocean Acidification. Oslo, Norway: Arctic Monitoring and Assessment Programme (AMAP); 2013. p. viii+99.

6. Anisimov OA, Vaughan DG, Callaghan TV, Furgal C, Marchant $\mathrm{H}$, Prowse TD et al. Polar regions (Arctic and Antarctic). Climate change 2007: impacts, adaptation and vulnerab ility. contribution of working group II to the fourth. In: Change ML, Parry OF, Canziani JP, Palutikof PJ, van der Linden, Hanson CE, (eds.) Assessment Report of the Intergovernmental Panel on Climate. Cambridge: Cambridge University Press; 2007. p. 653-85.

7. Holmes RM, McClelland JW, Peterson BJ, Tank SE, Bulygina E, Eglinton TI, et al. Seasonal and annual fluxes of nutrients and organic matter from large rivers to the Arctic Ocean and surrounding seas. Estuaries Coasts. 2012;35:369-82.

8. Fellman JB, Spencer RGM, Hernes PJ, Edwards RT, D’Amore DV, Hood E. The impact of glacier runoff on the biodegradability and biochemical composition of terrigenous dissolved organic matter in near-shore marine ecosystems. Mar Chem. 2010;121:112-22.

9. Hood E, Fellman J, Spencer RGM, Hernes PJ, Edwards R, D'Amore D, et al. Glaciers as a source of ancient and labile organic matter to the marine environment. Nature. 2009;462:1044-7.

10. Falk-Petersen S, Mayzaud P, Kattner G, Sargent JR. Lipids and life strategy of Arctic Calanus. Mar Biol Res. 2009;5:18-39.

11. Rhein M, Rintoul SR, Aoki S, Campos E, Chambers D, Freely RA et al. Observations: ocean. In: Stocker TF, Qin D, Plattner GK, Tignor M, Allen SK, Boschung J, (eds.) Climate Change 2013: the physical science basis. Contribution of working group I to the fifth assessment report of the intergovernmental panel on climate change. Cambridge, United Kingdom and New York, NY, USA: Cambridge University Press; 2013.

12. Ducklow HW, Steinberg DK, Buesseler KO. Upper ocean carbon export and the biological pump. Oceanography. 2001;14:50-8.

13. Eppley RW, Peterson BJ. Particulate organic matter flux and planktonic new production in the deep ocean. Nature. 1979;282:677-80.

14. Jiao N, Herndl GJ, Hansell DA, Benner R, Kattner G, Wilhelm $\mathrm{SW}$, et al. Microbial production of recalcitrant dissolved organic matter: long-term carbon storage in the global ocean. Nat Rev Microbiol. 2010;8:593-9.

15. Legendre L, Rivkin RB, Weinbauer MG, Guidi L, Uitz J. The microbial carbon pump concept: Potential biogeochemical significance in the globally changing ocean. Prog Oceanogr. 2015;134:432-50.

16. Polimene L, Sailley S, Clark D, Mitra A, Allen JI. Biological or microbial carbon pump? The role of phytoplankton stoichiometry in ocean carbon sequestration. J Plankton Res. 2017;39: 180-6.

17. Brussaard CPD, Bidle KD, Pedrós-Alió C, Legrand C. The interactive microbial ocean. Nat Microbiol. 2016;2:16255.
18. Widder S, Allen RJ, Pfeiffer T, Curtis TP, Wiuf C, Sloan WT, et al. Challenges in microbial ecology: building predictive understanding of community function and dynamics. ISME J. 2016;10:2557-68.

19. Landa M, Blain S, Christaki U, Monchy S, Obernosterer I. Shifts in bacterial community composition associated with increased carbon cycling in a mosaic of phytoplankton blooms. ISME J. 2016;10:39-50.

20. Jónasdóttir SH, Visser AW, Richardson K, Heath MR. Seasonal copepod lipid pump promotes carbon sequestration in the deep North Atlantic. Proc Natl Acad Sci USA. 2015;112:12122-6.

21. Schulz KG, Bellerby RGJ, Brussaard CPD, Budenbender J, Czerny J, Engel A, et al. Temporal biomass dynamics of an Arctic plankton bloom in response to increasing levels of atmospheric carbon dioxide. Biogeosciences. 2013;10:161-80.

22. Legendre L, Rassoulzadegan F. Food-web mediated export of biogenic carbon in oceans: hydrodynamic control. Mar Ecol Prog Ser. 1996;145:179-93.

23. Hessen DO, Ågren GI, Anderson TR, Elser JJ, de Ruiter PC. Carbon sequestration in ecosystems: The role of stoichiometry. Ecology. 2004;85:1179-92.

24. Thingstad TF, Havskum H, Zweifel UL, Berdalet E, Sala MM, Peters F, et al. Ability of a "minimum" microbial food web model to reproduce response patterns observed in mesocosms manipulated with N and P, glucose, and Si. J Mar Syst. 2007;64: $15-34$.

25. Larsen A, Egge JK, Nejstgaard JC, Di Capua I, Thyrhaug R, Bratbak $\mathrm{G}$, et al. Contrasting response to nutrient manipulation in Arctic mesocosms are reproduced by a minimum microbial food web model. Limnol Oceanogr. 2015;60:360-74.

26. Sandaa R-A, Pree B, Larsen A, Våge S, Töpper B, Töpper J, et al. The response of heterotrophic prokaryote and viral communities to labile organic carbon inputs is controlled by the predator food chain structure. Viruses. 2017;9:238.

27. Koroleff F. Determination of nutrients. In: Grasshoff K, Ehrhardt M, Kremling K, (eds). Methods in seawater analyses. Weinheim/ Deerfield Beach, Florida: Verlag Chemie; 1983. p. 125-31.

28. Valderrama JC. Methods of nutrient analysis. In: Hallograeff GM, Anderson DM, Cembella AD, (eds). Manual of harmful marine microalgae. IOC manuals and guides. Paris: UNESCO; 1995. p. 262-5.

29. Holmes RM, Aminot A, Keroul R, Hooker AH, Peterson BJ. A simple and precise method for measuring ammonium in marine and freshwater ecosystems. Can $\mathbf{J}$ Fish Aquat Sci. 1999;56:1801-8.

30. Cauwet G. Determination of dissolved organic carbon and nitrogen by high temperature combution. In: Grasshoff K, Kremling K, Ehrhardt M, (eds). Methods of Seawater Analysis. 3rd edn. Weinheim, Germany: Wiley-VCH Verlag GmbH; 1999. edn

31. Pella E, Colombo B. Study of carbon, hydrogen and nitrogen determination by combustion-gas chromatography. Microchim Acta. 1973;61:697-719.

32. Kwasniewski S, Hop H, Falk-Petersen S, Pedersen G. Distribution of Calanus species in Kongsfjorden, a glacial fjord in Svalbard. J Plankton Res. 2003;25:1-20.

33. Hay SJ, Kiørboe T, Matthews A. Zooplankton biomass and production in the North Sea during the Autumn Circulation experiment, October 1987-March 1988. Cont Shelf Res. 1991;11:1453-76.

34. Hay SJ, Evans GT, Gamble JC. Birth, growth and death rates for enclosed populations of calanoid copepods. J Plankton Res. 1988;10:431-54

35. Båmstedt U. Chemical composition and energy content. In: Corner EDS, O'Hara SCM, eds. The Biological Chemistry of Marine Copepods. Oxford: Clarendon Press; 1986. p. 1-58. 
36. Marie D, Partensky F, Vaulot D, Brussaard CP. Enumeration of phytoplankton, bacteria and viruses in marine samples. In: Robinson JP, (ed). Current Protocols in cytometry. New York, NY: John Wiley \& Sons; 1999.

37. Zubkov M, Burkill PH, Topping JN. Flow cytometric enumeration of DNA-stained oceanic planktonic protists. J Plankton Res. 2007;29:79-86.

38. Gasol JM, Zweifel UL, Peters F, Fuhrman JA, Hagstrom A. Significance of size and nucleic acid content heterogeneity as measured by flow cytometry in natural planktonic bacteria. Appl Environ Microb. 1999;65:4475-83.

39. Li WKW, Jellett JF, Dickie PM. DNA distributions in planktonic bacteria stained with TOTO or TO-PRO. Limnol Oceanogr. 1995;40:1485-95.

40. Longnecker K, Sherr BF, Sherr EB. Variation in cell-specific rates of leucine and thymidine incorporation by marine bacteria with high and with low nucleic acid content off the Oregon coast. Aquat Microb Ecol. 2006;43:113-25.

41. Morán XAG, Calvo-Díaz A, Ducklow HW. Total and phytoplankton mediated bottom-up control of bacterioplankton change with temperature in NE Atlantic shelf waters. Aquat Microb Ecol. 2010;58:229-39.

42. Proctor CR, Besmer MD, Langenegger T, Beck K, Walser J-C, Ackermann M, Bürgmann H, Hammes F. Phylogenetic clustering of small low nucleic acid-content bacteria across diverse freshwater ecosystems. ISME J. 2018;12:1344-59.

43. Scharek R, Latasa M. Growth, grazing and carbon flux of high and low nucleic acid bacteria differ in surface and deep chlorophyll maximum layers in the NW Mediterranean Sea. Aquat Microb Ecol. 2007;46:153-61.

44. Van Wambeke F, Catala P, Pujo-Pay M, Lebaron P. Vertical and longitudinal gradients in HNA-LNA cell abundances and cytometric characteristics in the Mediterranean Sea. Biogeosciences. 2011;8:1853-63. https://doi.org/10.5194/bg-8-1853-2011

45. Zhixin N, Huang X, Zhang X. Picoplankton and virioplankton abundance and community structure in Pearl River Estuary and Daya Bay, South China. J Environ Sci. 2015;32:146-54.

46. Holm-Hansen O, Riemann B. Chlorophyll a determination: improvements in methodology. Oikos. 1978;30:438-47.

47. Simon M, Azam F. Protein content and protein synthesis rates of planktonic marine bacteria. Mar Ecol Prog Ser. 1989;51:201-13.

48. Kirchman D. Leucine incorporation as a measure of biomass production by heterotrophic bacteria. In: Kemp PF, Sherr BF, Sherr EB, Cole JJ, (eds). Current methods in aquatic microbial ecology. London: Lewis Publisher; 1993. p. 509-12.

49. Schloss PD, Westcott SL, Ryabin T, Hall JR, Hartmann M, Hollister EB, et al. Introducing mothur: open-source, platformindependent, community-supported software for describing and comparing microbial communities. Appl Environ Microbiol. 2009;75:7537-41.

50. Quince C, Lanzen A, Davenport RJ, Turnbaugh PJ. Removing noise from pyrosequenced amplicons. BMC Bioinform. 2011;12:38.

51. Edgar RC, Haas BJ, Clemente JC, Quince C, Knight R. UCHIME improves sensitivity and speed of chimera detection. Bioinformatics. 2011;27:2194-200.

52. Needleman SB, Wunsch CD. A general method applicable to the search for similarities in the amino acid sequence of two proteins. J Mol Biol. 1970;48:443-53.

53. Gihring TM, Green SJ, Schadt CW. Massively parallel rRNA gene sequencing exacerbates the potential for biased community diversity comparisons due to variable library sizes. Environ Microbiol. 2012;14:285-90.

54. Polis GA, Sears ALW, Huxel GR, Strong DR, Maron J. When is a trophic cascade a trophic cascade? Trends Ecol Evol. 2000;15:473-5.
55. Carpenter SR, Kitchell JF, Hodgson JR. Cascading trophic interactions and lake productivity. Bioscience. 1985;35: 634-9.

56. Sommer U. Trophic cascades in marine and freshwater plankton. Int Rev Hydrobiol. 2008;93:506-16.

57. Alonso C, Pernthaler J. Roseobacter and SAR11 dominate microbial glucose uptake in coastal North Sea waters. Environ Microbiol. 2006;8:2022-30.

58. Satomi M, Fujii T. The family Oceanospirillaceae. In: Rosenberg E, Ed. The Prokaryotes: Gammaproteobacteria. Berlin, Heidelberg: Springer-Verlag; 2013. p. 491-529.

59. Gomez-Consarnau L, Lindh MV, Gasol JM, Pinhassi J. Structuring of bacterioplankton communities by specific dissolved organic carbon compounds. Environ Microbiol. 2012;14:2361-78.

60. Gómez-Pereira PR, Schüler M, Fuchs BM, Bennke C, Teeling H, Waldmann J, et al. Genomic content of uncultured Bacteroidetes from contrasting oceanic provinces in the North Atlantic Ocean. Environ Microbiol. 2012;14:52-66.

61. Kirchman DL. The ecology of Cytophaga-Flavobacteria in aquatic environments. FEMS Microbiol Ecol. 2002;39: 91-100.

62. Teeling H, Fuchs BM, Becher D, Klockow C, Gardebrecht A, Bennke CM, et al. Substrate-controlled succession of marine bacterioplankton populations induced by a phytoplankton bloom. Science. 2012;336:608-11.

63. Wilson B, Müller O, Nordmann E-L, Seuthe L, Bratbak G, Øvreås L. Changes in marine prokaryote composition with season and depth over an arctic polar year. Front Mar Sci. 2017; 4.

64. Lebaron P, Servais P, Agogué H, Courties C, Joux F. Does the high nucleic acid content of individual bacterial cells allow us to discriminate between active cells and inactive cells in aquatic systems? Appl Environ Microbiol. 2001;67:1775-82.

65. Jürgens K, Matz C. Predation as a shaping force for the phenotypic and genotypic composition of planktonic bacteria. Antonie Van Leeuwenhoek. 2002;81:413-34.

66. Mathisen P, Thelaus J, Sjöstedt de Luna S, Andersson A. Rapid adaptation of predation resistance in bacteria isolated from a seawater microcosm. Aquat Microb Ecol. 2016;78:81-92.

67. Baumgartner M, Roffler S, Wicker T, Pernthaler J. Letting go: bacterial genome reduction solves the dilemma of adapting to predation mortality in a substrate-restricted environment. ISME J. 2017;11:2258-66.

68. Matz C, Jürgens K. Interaction of nutrient limitation and protozoan grazing determines the phenotypic structure of a bacterial community. Microb Ecol. 2003;45:384-98.

69. Thingstad TF, Øvreas L, Egge JK, Løvdal T, Heldal M. Use of non-limiting substrates to increase size; a generic strategy to simultaneously optimize uptake and minimize predation in pelagic osmotrophs? Ecol Lett. 2005;8:675-82.

70. Longhurst AR. Ecological geography of the sea. Academic Press; Burlington 2010

71. Le Moigne FAC, Henson SA, Sanders RJ, Madsen E. Global database of surface ocean particulate organic carbon export fluxes diagnosed from the ${ }^{234} \mathrm{Th}$ technique. Earth Syst Sci Data. 2013;5:295-304.

72. Le Moigne FAC, Poulton AJ, Henson SA, Daniels CJ, Fragoso GM, Mitchell E, et al. Carbon export efficiency and phytoplankton community composition in the Atlantic sector of the Arctic Ocean. J Geophys Res Oceans. 2015;120:3896-912.

73. Kosobokova KN. The reproductive cycle and life history of the Arctic copepod Calanus glacialis in the White Sea. Polar Biol. 1999;22:254-63.

74. Lechtenfeld OJ, Hertkorn N, Shen Y, Witt M, Benner R. Marine sequestration of carbon in bacterial metabolites. Nat Commun. 2015;6:6711. 
75. Thingstad TF, Bellerby RGJ, Bratbak G, Borsheim KY, Egge JK, Heldal M, et al. Counterintuitive carbon-to-nutrient coupling in an Arctic pelagic ecosystem. Nature. 2008;455:387-37.

76. Edwards M, Richardson AJ. Impact of climate change on marine pelagic phenology and trophic mismatch. Nature. 2004;430:881-4.

77. Kraft A, Nothig EM, Bauerfeind E, Wildish DJ, Pohle GW, Bathmann UV, et al. First evidence of reproductive success in a southern invader indicates possible community shifts among Arctic zooplankton. Mar Ecol Prog Ser. 2013;493:291-6.

78. Weydmann A, Carstensen J, Goszczko I, Dmoch K, Olszewska A, Kwasniewski S. Shift towards the dominance of boreal species in the Arctic: inter-annual and spatial zooplankton variability in the West Spitsbergen Current. Mar Ecol Prog Ser. 2014;501:41-52. 